Marko Čudić

Univerzitet u Beogradu

https://doi.org/10.18485/bgd_nlistiek_30.2018.ch3

\title{
SLIKA NIZOZEMSKE U PUTOPISIMA DEŽEA KOSTOLANJIJA I ERŽEBET JUHAS
}

\begin{abstract}
The aim of this paper is to present the picture of the Netherlands in the travel writings of two Hungarian authors from different periods of the 20th century. The first text, written in 1931, entitled simply as Hollandia (Holland), is part of the collected travel writings Elsüllyedt Európa (Sunken Europe) by one of the most prominent figures of 20th century Hungarian literature, Dezső Kosztolányi (1885-1936). In this text, Kosztolányi emphasises the harsh contrast between his previous expectations (based on some of the most common stereotypes) and the reality he faces when he enters the country. In this context, this writing of his bears some of the most important common features of modernistic travel writings of the 20s and 30s. The second text taken into consideration, entitled József Attila út 31 (Attila József Road 31) was written by the relatively recently deceased post-modernistic Hungarian minority author from Vojvodina, Erzsébet Juhász (1947-1998), and published in 1998 in her collection of essays Uttalan utaim (My Roads that Lead to Nowhere). It is primarily an intertextual dialogue with the verses of the great 20th century Hungarian poet, Attila József (19051937), rather than a standard travel writing, written in a deeply pessimistic, almost apocalyptic tone.
\end{abstract}

Keywords: Picture of the Netherlands, Hungarian literature, modernistic and postmodernistic travel writings.

\section{Uvodne napomene}

Sve negde do poslednjih decenija dvadesetog veka, istoričari i teoretičari književnosti gledali su na putopis - posebno u okviru opusa značajnih i plodnih pisaca - kao narubni, periferni, manje značajan žanr ili žanrovski hibrid, kao na nekakav, kako ga Slobodanka Peković, ne bez fine naučničke ironije u kontekstu svoje studije, naziva, „inferiorni podžanr” (Peković 2001: 11). Tek će značajniji prodor interdisciplinarnih i kulturalnih studija u diskurs teorije književnosti omogućiti da putopis postane predmetom življeg interesovanja. To naročito važi za oblast imagologije i izučavanja onoga što se danas, u najopštijem smislu, određuje kao pogled na Drugo/Drugog, na Strano/Stranca. Postkolonijalna kritika i teorija teško se mogu zamisliti bez kritičke elaboracije putopisa i iz nje proishodećih, često i preterano dalekosežnih, a neretko 
i vrlo diskutabilnih uopštavajućih zaključaka. Dihotomija centralno (iliti tlačiteljsko, kolonizatorsko, zapadnjačko) - periferno (rubno, provincijsko, istočnjačko i tome slično) i njena kritička analiza, neke su od centralnih kategorija kojima barataju predstavnici postkolonijalnog pogleda na svet, koji i sami najčešće dolaze iz ovako shvaćenih „rubnih” područja sveta (Edvard Said, Marija Todorova, da pomenemo samo neke od najuticajnijih). Kad je reč o analizi putopisa, privilegovano mesto ovako shvaćene kritičke elaboracije zauzimaju autori iz velikih, uticajnih kultura i njihovo, najčešće snažnim stereotipima obeleženo viđenje manjih, „zaostalijih” kultura. Takav odabir veoma je logičan, ako se zna da je iz raznoraznih razloga, no ponajviše kolonijalno-kolonizatorskih i ekonomskih, takozvano putovanje iz zadovoljstva, sve do pred kraj devetnaestog veka, odista uglavnom bilo isključiva privilegija bogatijih pripadnika većih, uglavnom zapadnoevropskih nacija sa kolonijalnom prošlošću ili sadašnjošću.

Tek će opšti razvoj, omasovljavanje i veća dostupnost prevoznih sredstava, te polet (masovnog) turizma, omogućiti da i autori koji pišu na jezicima manjih, rubnih kultura Evrope i sveta, dobiju priliku i steknu „doživljajni materijal” kako bi se mogli okušati u (pod)žanru (književnog) putopisa. Među istraživačima postoji konsenzus o tome da je književni putopis, osobito u Evropi, svoj istinski procvat doživeo upravo u prvoj polovini dvadesetog veka, ili, još preciznije omeđeno, u periodu između dva svetska rata (Gvozden 2011: 6). U tom kontekstu, autori iz mađarskog govornog područja mogli bi se shvatiti kao, u izvesnom smislu, postimperijalni pisci. Predmet analize ovog rada biće dva putopisa dvoje mađarskih pisaca iz različitih perioda dvadesetog veka, klasika mađarske „estetske moderne”, Dežea Kostolanjija (Kosztolányi Dezső, 1885-1936) te savremene spisateljice iz Vojvodine, Eržebet Juhas (Juhász Erzsébet, 1947- 1998).

\section{Slika Nizozemske u zbirci putopisa Potonula Evropa Dežea Kostolanjija}

Kostolanji za života nije sakupio i objavio svoje putopise u obliku knjige. Ta filološka činjenica mogla bi poslužiti kao osnov za pretpostavku da je i sam smatrao putopis ne previše značajnim žanrom, da ga je svrstavao u neku vrstu publicistike. Isto tako, činjenica da se u inače vrlo bogatoj mađarskoj stručnoj literaturi o Kostolanjiju ${ }^{1}$, tek teoretičar mlađe generacije Laslo Bengi (Bengi László, rođ. 1976. godine), sistematičnije

1 Zanimljivo je da se sa ozbiljnijim naučnim proučavanjem Kostolanjijevog opusa počelo tek sa proslavom stogodišnjice piščevog rođenja, 1985. godine. Nije nemoguće da su u tom „ponovnom otkrivanju” Kostolanjija važnu ulogu imale i promenjene društvenopolitičke okolnosti - postepeno labavljenje stega (real)socijalizma u državi pod vođstvom već ostarelog Janoša Kadara (Kádár János, 1912-1989), brz prodor novih-starih građanskih ideja, ali i, danas već, naročito u mađarskim kritičarskim krugovima, čuveni zaokret ka postmodernizmu mađarskog romana, koji se uglavnom vezuje za 1979. godinu, kada je Peter Esterhazi (Esterházy Péter, 1950-2016) objavio svoj znameniti Proizvodni roman (Termelési regény) (videti Kulcsár-Szabó 1994: 160-176). 
posvetio istraživanju poetičkih odlika Kostolanjijevih putopisa, tretirajući ih kao književne tekstove prvoga reda, ide u prilog tezi da ni sami istraživači Kostolanjijevog opusa nisu, sve do nedavno, njegove putopise smatrali u književnom smislu preterano značajnim tekstovima.

Putopise Dežea Kostolanjija za štampu je priredio i predgovorom opremio njegov mlađi savremenik, pesnik, prozaista i sociograf Đula Ilješ (Illyés Gyula, 19021983), istaknuti predstavnik takozvane „narodnjačke struje” u mađarskoj književnosti dvadesetog veka. Ova posthumno priređena knjiga Kostolanjijevih putopisa nosi znakovito pesimističan naslov Potonula Evropa (Elsüllyedt Európa), i sadrži Kostolanjijeve putopise nastale u periodu između 1909. i 1935. godine. Ovi putopisi imaju mnoge poetičke odlike modernističkog putopisa - izraziti subjektivizam i prilično česti esejističko-filozofski pasaži, namerna distanciranost od masovnog turizma, izbegavanje pisanja o isuviše dobro poznatim znamenitostima koje pominju svi bedekeri ${ }^{2}$, samo su neke od ovih odlika.

Kostolanji je u Holandiji proveo dva meseca, avgust i septembar 1931. i to svoje putovanje ovekovečio je u putopisu vrlo jednostavnog naslova Holandija (Hollandia). Ovaj Kostolanjijev putopis od dvadesetak stranica ne bi trebalo, međutim, zamišljati kao nekakav odeliti „putopisni blok” u kojem se sistematično opisuju predeli Nizozemske kroz koje prolazi i Nizozemci sa kojima se pisac usput susreće. Naprotiv. Naime, fragmentarnost i relativno slobodan sled asocijacija, te nizanje slika koje bi se najopštije mogle odrediti kao „trenutni snimci sa puta” opšta je odlika svih Kostolanjijevih putopisa koju je zapazio i Laslo Bengi (Bengi 2012: 11). No, neka elementarna hronologija ipak postoji. Jedna od tipičnih odlika Kostolanjijevih putopisa jeste i stvaranje atmosfere grozničavog iščekivanja i zamišljanja destinacije u koju se uputio:

Iščekujem tvoj dolazak, Holandijo, poput nekog nestrpljivog klipana. Već satima se vrzmam po vozu, trčkaram hodnikom, pijem crno vino u kolima za ručavanje, ispijam kafu i pušim, ne bih li i na taj način požurivao lokomotivu. [...] Zamišljam te kao dadilju, starinsku, krupnu dadilju koja doji, koja privija na svoje grudi svako kržljavo odojče, koja svako malokrvno detence priljubljuje na svoju dojku [...] (Kosztolányi 1996: 137). ${ }^{3}$

Putopisac očekuje (bolje rečeno, pravi se da očekuje) da će zateći sliku Nizozemske najsličniju onoj koju je u svojoj čuvenoj pesmi Holandski predeo opisao italijanski pesnik Edmondo de Amičis, a koje se seća iz detinjstva, ali i iz svog sadašnjeg (tadašnjeg) udžbenika italijanskog jezika. Takva očekivanja biće, razume se, brzo izneverena. Velika količina živopisnih vetrenjača i seljaka u klompama svakako nisu prizori koje Kostolanji u avgustu 1931. godine zatiče pri prelasku holandske granice.

\footnotetext{
2 Ukoliko se i pominju ili opisuju neke znamenitosti, onda se to čini iz neke sasvim drugačije, neočekivane perspektive i u sasvim drugom kontekstu.

3 Svi prevodi odlomaka mađarskih tekstova su moji (M. Č.).
} 
Laslo Bengi ovu pojavu izneveravanja putnikovih očekivanja naziva „uzbuđena razočaranost" i smatra da je ovaj tip antiteze između očekivanja i zatečene stvarnosti čest novinarsko-reportažni trik, osobito u putopisima toga vremena (Bengi 2012: 26). Činjenica da u modernističkom putopisu dugo iščekivani „hronotopi više ne odgovaraju zatečenoj stvarnosti” (Gvozden 2011: 32), drugim rečima, vrtoglavo iščezavanje nacionalnih osobenosti na kojima su se zasnivali putnički stereotipi ranijih epoha, rezultat su ne samo brzog tehnološkog napretka, već i jedne opšte duhovne atmosfere koju hrvatski teoretičar „putničke tekstualnosti” Dean Duda označava kao „spacijalno centripetalna »drama napretka«" (Duda 2012: 184).

Ironija kojoj je u svojoj prozi Deže Kostolanji izrazito sklon, ne napušta ga ni prilikom pisanja putopisa. Ta sklonost ka ironiji omogućuje mu da samoga sebe posmatra u svetlu drugog, na primer, kada sa dozom snažne ironije poredi svoje trenutno „putopisno Ja” sa stranim turistima koji u njegovu domovinu, Mađarsku, dolaze sa ogromnim prtljagom stereotipa i odista iritantno smešnih predrasuda:

Sada podsećam na one strance koji, istog trena kad stignu kod nas, uskliknu: „pustara, čikoši, čardaš”. Koliko sam ih samo, siromahe, prezirao zbog toga. I koliko je samo njih, jadne, bolelo kada sam im, vrlo obazrivo, davao do znanja da Andrašijev bulevar nije baš prava pustara, da u našim književnim kafeima ne sede sve sami čikoši, da muzika Franca Lista i Bele Bartoka nije isto što i ciganske melodije. U svima nama stanuje jedan nepopravljivi deran i pustolov, i srce nam se cepa kada stvarnost demantuje naše petparačke etnografske maštarije. [...] Ali, šta mi tu možemo, ako je njima baš to sinonim za „mađarsko”? Toga se ljubomorno drže. Ne možemo im osporiti to pravo. A drže se i toga da sam ja „vatreni Mađar”. Stigao sam među njih sav slabašan, nisam prozborio ni reči, zevao sam i kašljao. Pa ipak, pozdravili su me usklikom: „Vatreni Mađaru!” (Kosztolányi 1996: 138-139).

Slično većini svojih modernističkih savremenika, i Kostolanji spada u one putopisce koji preziru masovni turizam i ne smatraju da je doživljaj u vidu nekog unapred očekivanog prizora centralni razlog i „sveti gral” putovanja. Naprotiv, u jednom esejističkom pasažu umetnutom u svoj nizozemski putopis, u svojevrsnom minieseju, koji se može čitati i kao nekakva osobena kostolanjijevska „filozofija putovanja” ili barem kao autopoetička legitimacija Kostolanjijevog putopisnog creda, ovaj pisac pomalo neočekivanim obrtom izvodi logički zaključak da upravo to razočaranje uslovljeno izneverenim očekivanjima predstavlja ono što jeste, zapravo, suštinski doživljaj putovanja:

$\mathrm{Na}$ putovanju, dakle, uvek doživljavamo razočaranje. Ne dobijamo ono što smo očekivali, već nešto drugo. Često manje, no upravo zbog toga i više. Kad bismo dobijali samo ono što očekujemo, ono mnogo, onda bi izostalo iznenađenje. To razočaranje je zapravo istinski doživljaj putovanja. Reč je o plodonosnom uzbuđenju koje nastaje iz sučeljavanja, iz iskričavog sudara mašte i stvarnosti. Samo nam je potrebna sposobnost da ga iskoristimo i da naučimo našu maštu da se prilagodi stvarnosti (Kosztolányi 1996: 139). 
U svetlu ovakvog Kostolanjijevog pristupa putovanju, postaje sasvim jasno zbog čega od ovog pisca ne možemo očekivati hronološki ustrojen i iscrpan, verodostojan prikaz tadašnje holandske svakodnevice. Ipak, ako bismo morali izdvojiti neki opšti utisak koji Holandija ostavlja na putopisca Kostolanjija, onda bi to u prvom redu bio utisak blagostanja i bogatstva, mirnog života u izobilju, za koje, po piščevom mišljenju, postoje dva razloga. Prvi je često isticana neverovatna marljivost, štedljivost i upornost Holanđana. I Kostolanji se, naime, pridružuje velikom nizu putopisaca koji se dive holandskom „osvajanju zemlje”, njenom „otimanju od mora”; taj fenomen Kostolanji čak poredi za čuvenom mađarskom rečju honfoglalás (doslovno „osvajanje domovine”, izraz kojim se označava prodor, prema legendi, sedam proto-mađarskih plemena u Karpatski basen krajem devetog veka naše ere), te ga naziva nekom vrstom „novog osvajanja domovine” (Kosztolányi 1996: 141). Drugi razlog tog blagostanja u Kostolanjijevoj vizuri, Holanđanima baš i ne služi naročito na čast: „Na svakog Holanđanina dolazi po sedmoro slugu iz kolonija”, kaže putopisac samo nekoliko redaka dalje (Kosztolányi 1996: 141). Vidimo, dakle, da ni Kostolanji, ma koliko se trudio i tvrdio suprotno, nije sasvim imun na stereotipe.

Bogatstvo kao centralni Kostolanjijev utisak o Holandiji, kad je o konkretnim primerima reč, prikazano je, takođe, sa dozom tipično kostolanjijevske ironije, mada ona ume katkad da bude i na granici sarkazma: „Jedan arheolog pozvao me je na ručak. Živi u stanu od šest soba. [...] Ovaj arheolog nije bogat čovek. Reč je jednostavnom, skromnom trudbeniku nauke." (Kosztolányi 1996: 140). Gorka ironija još je očiglednija kada putopisac govori o ukupnoj materijalnoj vrednosti Rajksmuzeuma: „Neko je izračunao da ova galerija sa svojim slikama vredi više od mirnodopske Crne Gore i Albanije, sa svim njihovim planinama, oranicama, kućama, konjima, kravama i kozama zajedno" (Kosztolányi 1996: 140).

\section{Eržebet Juhas - intertekstualni (put)opis vlastitog duševnog stanja}

Veoma nestandardni, postmodernistički, citatima i refleksijama zasićeni putopis pod naslovom Put Atile Jožefa 31 (József Attila út 31) deo je zbirke eseja i putopisa vojvođanske spisateljice Eržebet Juhas Moja bespuća (Úttalan utaim), objavljene 1998. godine. Knjiga je svojevrsna hronika sveopšteg materijalnog, moralnog i intelektualnog propadanja Srbije devedesetih godina prošlog veka, prikazana iz trostruke manjinske vizure (vojvođansko-mađarske, ženske i građanske) jedne hiperosetljive intelektualke. Perspektiva svih ovih eseja izrazito je introvertna. U tom smislu, ne može se govoriti o bilo kakvom nastavljanju tradicije modernističkog putopisa, pa čak ni o njegovoj postmodernističkoj parodiji. Podnaslov knjige - Útleírások a Vajdaságból - mogao bi se prevesti i tumačiti dvojako, budući da se formulacija Putopisi iz Vojvodine može odnositi na to da je reč o putopisima iz pera vojvođanskog autora/autorke, no taj bi se podnaslov mogao tumačiti i tako da se akcenat stavi na tačku iz koje se (svaki put) polazi, dakle, na činjenicu da je reč o putovanjima na koja se kreće, koja se preduzimaju $i z$ Vojvodine, sa primetnom dozom jedne bespomoćne autoironije spram vlastitog provincijalnog položaja i životarenja na kulturnom i civilizacijskom rubu Evrope, 
potonulom u varvarstvo i militantnu mržnju.

Glavna tema ovog takozvanog putopisa trebalo bi da bude spisateljičin izlet u Amsterdam kod njene prijateljice, vojvođanske Mađarice koja živi u Amsterdamu i u braku je sa Holanđaninom. No, mnogo je više ovde reč o preciznoj topografiji vlastitih móra i strahova, vlastite duboke depresije i egzistencijalne krize, pa čak i duboke krize svog nacionalnog, jezičkog i civilizacijskog identiteta. Tekst je prošaran stihovima velikog mađarskog pesnika Atile Jožefa (József Attila, 1905-1937), koji je izvršio samoubistvo 1937. godine, u trideset trećoj godini života. Pripovedačica govori o sebi u trećem licu:

Pomislila je (ona, a ne ja, ne bih mogla u potpunosti da se identifikujem sa njom, sa njom imam veze kao što bih imala, recimo, sa nekom izraslinom na telu ili mozgu, ili je možda tumor pravi izraz? - jednom rečju, ona je žarište koje pripada meni, a ipak nije organski ugrađeno u moje biće). Da počnem ispočetka: pomislila je da nema većeg poklona od prilike da otputuje s ružnog, razvaljenog poprišta svoje svakodnevice, za koje je samo još vlastita nemoć vezuje, mada vrlo snažno, te stoga nikako ne bi bila u stanju prihvatiti iskušenja selidbe, trajne promene prebivališta (Juhász 1998: 65).

Izlet od svega nekoliko dana u Amsterdam ne shvata se ovde kao mogućnost da se na trenutak odvoji od tužne realnosti, već poprima mitske razmere. Imajući u vidu stil Eržebet Juhas (duge, vijugave rečenice, misao koja se grana u više različitih pravaca) duže citate je, praktično, nemoguće izbeći:

Krišom je možda ipak računala na to da će ovako, ako i mene povede sa sobom, moći da ukine tešku suprotnost koju ova dva dijametralno sučeljena sveta, Balkan i Holandija, predstavljaju? Ili se zavaravala time da je Holandija samo kodno ime za Nakonksipan, te da će iz ovog i te kako stvarnog sveta uspeti da ode u jedan nepostojeći?

I pored sve svoje besmislenosti, odnosno nerešivosti, biće da ju je na ovo putovanje podsticala želja za nestajanjem.

Kako je samo odlučno u vreme svojih nekadašnjih bombastičnih tugovanja govorila, ko bi gajdaš hteo biti, mora pakla pohoditi, tamo će se namučiti i gajdama naučiti ${ }^{4}$, zamišljajući da je ovaj put što vodi u pakao njena lična posebna vožnja i da samo od nje zavisi hoće li se ukrcati na nju ili neće. [...] Nije, međutim, očekivala da će nastupiti takva vremena da neće ona biti ta koja će se spustiti u dubine pakla, već da će se sam pakao podići iz svoje, kako se verovalo, metafizičke dubine, te da će se proširiti oko nje poput noći predgrađa u kojoj nikada neće osvanuti zora (Juhász 1998: 68-69).

4 Ovo nije direktan citat pesme Atile Jožefa, već je reč o stihovima koje je ovaj pesnik stavio kao moto svoje zbirke izabranih pesama, objavljene 1934. godine pod naslovom Medvetánc (Mečkin ples), a koje sam pesnik naziva pastirskom poskočicom, dakle, produktom (mađarskog) „narodnog genija”. Ove stihove ovde navodimo u prevodu Danila Kiša, koji ih je stavio kao moto svog izbora prevoda poezije Atile Jožefa, pod naslovom Noć predgrađa. (József 2005: 11). 
Eržebet Juhas daje zanimljivu definiciju (svog) putovanja, kada se jada: „Gospode, kako je samo mučno i gorko ovo mucanje (bića) kada je prerušeno u putovanje!” (Juhász 1998: 70). Ovaj introvertni putopis lišen je gotovo bilo kakvih opisa grada u kojem se boravi. Čak i holandski jezik, koji ne razume, podseća spisateljicu na vlastiti marginalni, manjinski bitak i na vlastiti maternji jezik. Pojavljuje se apokaliptična vizija o njegovom konačnom gubljenju: „U fazi sporog, ali nezadrživog zaboravljanja jezika, osluškivanje jednog potpuno nepoznatog jezika može se uporediti jedino sa muzikom" (Juhász 1998: 72).

Eržebet Juhas se, na izvestan način, $u$ ovom svom postmodernističkom putopisu, nalazi u stanju neskrivenog dijaloga sa poezijom Atile Jožefa. Potpomognuta citatima iz njegovih pesama, ona se vraća konceptu putovanja kao traganja za epifanijskim trenucima samospoznaje u miljeu (radikalno) drugačijem od vlastitog. Ta će samospoznaja, međutim, biti krajnje pesimistična, besperspektivna:

No, sve je snažnije osećala da ispod površnih radosti i zadivljenosti njene duše zjapi praznina koja se drznula da opasno poraste i time njenu radost i zadivljenost sve više slabi i cepa. Sve ju je više mučio osećaj da ništa, pod milim bogom ništa nije u stanju da upije od ovoga grada, te da će se ovaj neočekivani poklon u vidu njenog boravka ovde završiti mračnom spoznajom da je jedino još u raspadanju kadra da se snađe. Odnosno, da više nije u stanju da igde bude prisutna, te da je, ma gde se nalazila, sposobna još samo za uzmicanje. Da sva ona mesta koja pružaju pogled na bilo kakav iole humani život, kulturu, umetnost, lepotu i harmoniju, nju zapravo više i ne dotiču. Da sve potrebe ove vrste otpadaju sa nje, kao što $s$ drugih otpada odeća u blaženom ljubavnom zagrljaju. (Juhász 1998: 72-73). ${ }^{5}$

Pa ipak, uprkos ovim apokaliptičnim tonovima, ovoj, gotovo mazohističkoj autodijagnozi, uprkos spoznaji da bi ova definitivna izopštenost iz bogatstva, blagostanja i bilo kakve mogućnosti iole mirnog i spokojnog života mogla čak značiti i to da bi ovo mesto (Holandija) za nju moglo da predstavlja i „živi pakao“ (Juhász 1998: 76), pomalo iznenađuje završni akord ovog (kvazi) putopisa, da upravo u toj strašnoj spoznaji ona pronalazi smirenje. Time kao da se, na prilično groteskni način, potvrđuje jedan od starih toposa putovanja, prema kojem putovanje proizilazi iz nemira, a da mu je krajnji cilj pronalaženje duševnog mira. Ili se, pak, taj topos radikalno izvrgava ruglu, zavisi od ugla posmatranja.

5 Ova poslednja rečenica je direktan citat iz pesme Nagyon fáj Atile Jožefa, koju je Danilo Kiš preveo kao Boli. Stihovi u originalu glase: A kultúra/úgy hull le rólam, mint ruha/másról a boldog szerelemben (József 2005: $86-87)$. 


\section{Zaključna razmatranja}

Činjenica je da se o Nizozemskoj ne bi moglo, poput, recimo, Pariza, Italije ili Bliskog istoka, govoriti u kontekstu „povlašćenog mesta putopisne tradicije” (Gvozden 2011: 55), naročito kad je reč o putopisima autora iz Srednje i Istočne Evrope. Relativno mali broj ovakvih putopisa u (novijoj) mađarskoj književnosti svakako da ne pruža dobru osnovu za donošenje bilo kakvih ambicioznijih sintetičkih zaključaka.

Dva teksta koja su bila predmet analize ovoga rada, s obzirom na vreme njihovog nastanka i poetičke odlike, mogu se čitati kao reprezentativni uzorci modernističkog, odnosno postmodernističkog putopisa u mađarskoj književnosti dvadesetog veka. Kostolanjijev putopis sadrži elemente koje Dean Duda određuje kao opšte odlike postmodernističkog rukopisa, kada kaže: „Modernistički putopis, konkretnije putopis dvadesetih i tridesetih godina, naglašava temu samoootkrivanja i funkcionira poput dvoplanskoga teksta s tobože jakom realističkom površinom koja je često zapravo parabola" (Duda 2012: 200).

U putopisu Eržebet Juhas iz poslednje decenije devedesetih godina gubi se ta jaka realistička površina, i njen tekst, iz kojeg su gotovo potpuno odsutne bilo kakve konkretne slike sa putovanja, načičkan mnogobrojnim citatima stihova Atile Jožefa, odista funkcioniše kao intertekstualno putovanje po vlastitoj duši. Ako je Laslo Bengi povodom Kostolanjijevih putopisa, sasvim bartovski, s pravom primetio da je putopis zapravo neka vrsta „procesa semiotizacije”, gde čak i ono što domaće stanovništvo uopšte ne doživljava kao bilo kakav znak, gost-putopisac tumači upravo na taj način, često učitavajući odlike znaka i tamo gde nikakvog znaka nema (Bengi 2012: 69), onda se u slučaju Eržebet Juhas može govoriti o gotovo apsolutnoj „desemiotizaciji”, u kojoj putopis gubi jednu od svojih najvažnijih karakteristika, pa je veliko pitanje može li se uopšte u njenom slučaju govoriti o putopisu u osnovnom značenju te reči. Velika razlika je i u tome što Kostolanji piše iz relativno komotne pozicije priznatog, etabliranog mađarskog pisca, gotovo neke vrste „živog klasika”, koji živi i stvara u Budimpešti, centru mađarskog književnog života i svog i današnjeg vremena, dok Eržebet Juhas piše iz višestruke manjinske pozicije: iz pozicije predstavnice mađarske književnosti u Vojvodini, iz pozicije naglašeno ženskog "putujućeg subjekta”, te iz pozicije građanske intelektualke u (post) komunističkoj epohi, u trenucima kada su, zbog ratnog meteža i raspada bivše Jugoslavije, dešavaju vrtoglavo brze sveopšte promene mentalitetskih obrazaca, pa i elementarne ljudskosti. Uočava se, međutim, bez obzira na ove inherentno različite pozicije ova dva putopisca, i jedna važna zajednička odlika ovih tekstova: pomalo rezignirano-melanholični Kostolanjii veoma rezignirano-depresivna Juhasova nastupaju i pišu iz pozicije (puto) pisaca koji, konkretno u slučaju Nizozemske, govore o bogatstvu ove zemlje kontrastirajući ga sa relativnim (Kostolanji) ili gotovo apsolutnim (Juhas) siromaštvom svojih domovina, iz pozicije nekoga ko je u svojoj domovini ipak u prošlosti video i doživeo znatno bolja vremena od sadašnjih (odnosno od vremena u kojima ovi putopisi nastaju).

U tom kontekstu, ne bi čak preterano bilo reći da i u slučaju Kostolanjija i u slučaju Eržebet Juhas, možemo govoriti o određenim tipovima postimperijalnih putopisa. Kostolanji je, naime, kao dečak i mladić, bio svedok kulturnog i ekonomskog 
procvata Mađarske (države koja je u to vreme, u okviru dvojne, Austrougarske monarhije, zauzimala teritoriju gotovo triput veću nego danas) u vreme i nakon Milenijumske izložbe 1896. godine, kada se slavila hiljadugodišnjica doseljavanja Mađara u Karpatski basen. U tom smislu, krah nakon Prvog svetskog rata, a pogotovo Trijanonski sporazum iz 1920. godine, kojim je Mađarskoj oduzeto oko dve trećine teritorija, u situaciji kada se nekoliko miliona Mađara naprasno našlo u statusu (mahom ugnjetene) nacionalne manjine u susednim državama, izvršio je vrlo traumatičan uticaj na Kostolanjija. Posebno zbog biografske činjenice da se Kostolanjijeva porodica (otac, majka, sestra i brat) u Subotici iznenada našla u novoj državi, kraljevini SHS, bez znanja jezika i lišena dobrog dela građanskih prava, pa i zaposlenja (slučaj Kostolanjijevog brata Arpada, lekara). Uostalom, iako ovakva svedočenja iz druge ruke ne mogu da se uzmu kao pouzdano svedočanstvo, sâm Kostolanji je na samrtnoj postelji piscu Šandoru Maraiju navodno rekao: „Mađarski pisac umire od Trijanona” (Szegedy-Maszák 2010: 165).

Eržebet Juhas, s druge strane, već pripada tzv. drugoj posttrijanonskoj generaciji Mađara van matične države, i njeno iskustvo posedovanog, pa izgubljenog bogatstva - pri čemu se, naravno, ovde mnogo više misli na kulturno bogatstvo i raznolikost, nego na materijalno - odnosi se na mladost provedenu u SFRJ, koja se u zrelim spisateljičinim godinama na najkrvaviji način ruši, ostavljajući i inače antiprovincijalno nastrojenu autorku okruženu sve teže uočljiivim razvalinama njenog nekadašnjeg života. U tom smislu, Nizozemska kao poredbena osnova kod nje, mnogo više nego kod Kostolanjija, funkcioniše kao još veći i bolniji, za nju zauvek nedostižni antipod njenoj aktuelnoj situaciji, i kao čemerno podsećanje da je takav, bogat i raznovrstan život, negde još uvek moguć. No, to mesto izobilja svakako nisu krhotine njene nekadašnje domovine.

\section{Literatura}

Bengi László. 2012. Elbeszélt halál. Kosztolányi tanulmányok. [Ispripovedana smrt. Studije o Kostolanjiju]. Budapest: Ráció Kiadó.

Duda, Dean. 2012. Kultura putovanja. Uvod u književnu iterologiju. Zagreb: Naklada Ljevak.

Gvozden, Vladimir. 2011. Srpska putopisna kultura 1914-1940. Studija o hronotopičnosti susreta. Beograd: Službeni glasnik.

József Attila. 2005. Noć predgrađa. Preveo s mađarskog Danilo Kiš. Novi Sad: Forum.

Juhász Erzsébet. 1998. „József Attila út 31”. Úttalan utaim. Novi Sad: Forum, pp. 65-77.

Kosztolányi Dezső. 1996. „Hollandia”. Elsüllyedt Európa. Budapest: Rejtjel Kiadó, pp. 137-159.

Kulcsár Szabó Ernő. 1994. A magyar irodalom története 1945-1991. Budapest: Argumentum Kiadó. 
Peković, Slobodanka. 2001. „Putopis - uslovljenost žanra”. Peković, Slobodanka (ed.), Knjiga o putopisu. Zbornik radova. Beograd: Institut za književnost i umetnost, pp. 11-26.

Szegedy-Maszák Mihály. 2010. Kosztolányi Dezső. Pozsony: Kalligram. 